Dragana Vasilijević

Faculty of Philology

University of Belgrade
UDC 323.15(=161.2)(497.6)

DOI https://doi.org/10.18485/fid.2017.7.ch9

\title{
THE CURRENT STATE AND PROSPECTS OF UKRAINIAN AS A HERITAGE LANGUAGE IN ELEMENTARY SCHOOLS OF REPUBLIKA SRPSKA
}

Због дуготрајног недостатка контакта са својом домовином, и великог броја мешовитих бракова, босански Украјинци говоре језиком који се веома разликује од језика који се данас говори у Украјини. За већину становништва украјински више није Л1 и њихов национални идентитет се углавном чува у цркви и кроз обичаје (прославе, традицију, фолклор) док са̂м језик има споредну улогу.

Теренска истраживања посвећена украјинском као језику наслеђа у основним школама у Републици Српској спроведено је у местима Прњавор и Насеобина Лишња у новембру 2014. године. Идентификовани су следећи већи проблеми и изазови са којима се Украјинци суочавају у процесу усвајања језика у школи: недовољна средства, слаба заинтерсованост родитеља, оскудан и неодговарајући наставни и помоћни материјали за учење, проблеми у организацији у школама и недостатак ваннаставних активности у вези са украјинским језиком.

Кључне речи: украјински као језик наслеђа, украјинска дијаспора, босански Украјинци, мањине у Републици Српској.

\section{Introduction}

The Bosnian Ukrainians settled Prnjavor and its surroundings at the end of $19^{\text {th }}$ century. Like most of the Slavic minority groups, they are relatively old settlers in this area, meaning that they are recognized by the authorities as a national and language minority (Gustavsson 1998: 175).

Therefore, they have legislative, institutional and to some extent financial support for preservation and development of their cultural heritage and language. Regardless of this, the community faces a wide range of difficulties in maintaining their language, caused by not only long-lasting isolation from "Matica" (the motherland), but also by financial and organizational issues, and problems inside the community itself. 
The historical aspects of the Ukrainian Diaspora in the Balkans and especially Bosnia and Herzegovina have so far been well researched by different authors (mostly of Ukrainian background) who were interested in the circumstances of their arrival and further migrations (Румянцев 2008; Небесниј 2007; Малиновська 1995; Strehaljuk 1980; Марунчак 1969; Krojcar 1927), history, life and culture of the local diasporan community (Саган 2014; Микитенко, 2012; Румянцев 2010; Sančanin 2005; Латяк 2000; Ліський 1997; Козлітін 1996; Терлюк 1996). Previous researchers also paid special attention to problems of national identity of Ukrainians in wider Balkan context particularly emphasizing Ruthenian-Ukrainian relations (Журжа 2014; Поповић 2010; Sabadoš 1971; 1973).

On the other hand, the language of Bosnian Ukrainians has so far been the subject of a small number of overview papers written by different authors (Белей 2008; Стрехалюк 1985; Коваль 1967 about the local language variety in general; Strehaljuk 1984a; 1984b; 1987; Головчук 2007 about Ukrainian language within the educational system of Bosnia and Herzegovina) and a dialectological study conducted by Tamara Tokar in the early 1970s. This field research resulted in her $\mathrm{PhD}$ thesis, a series of papers and an article in the Encyclopedia of Ukrainian Language (Токар 1972a; 1972b; 1973; 1981a; 1981b; 1991; 1997).

\section{Bosnian Ukrainians - Background and Identity}

Ukrainians living in Republika Srpska $(\mathrm{BiH})$ belong to the second wave (Марунчак 1969: 45; Белей 2008: 43) of Ukrainian migration, which settled the Balkans as a part of internal colonization, after the Congress of Berlin (1878), but before the official Austro-Hungarian annexation of Bosnia (1909). The biggest migration flow arrived to Prnjavor and its surroundings between 1898 and 1901 and, judging by available sources, consisted of 12-14 thousands Ukrainians (Nebesnij 2007: 547) most from Galicia (cities of: Tovmač, Brodi, Ternopolj, Rogatin, Bučač, Rava-Ruska, etc.), more rarely Northern Bukovina and Zakarpattya. The new settlers named themselves "Ukrainians", Austro-Hungarian officers referred to them as Ruthenians and the local population called them Galicians (Nebesnij 2007: 547). 
In spite of their poor material conditions, The Ukrainians have been actively working on preserving their cultural and national identity from the moment of settlement. This is why the first Ukrainian parish in Prnjavor was formed in 1897, along with the first Church (1912). The first readingroom of the Prosvita Society was opened in Prnjavor in 1909, to be followed by others in Srpci, Mujinci, Banja Luka, Stara Dobrava, Kozarac and Kamenica.

Many Ukrainians abandoned Bosnia in the $20^{\text {th }}$ century within different migration flows heading to Vojvodina and Croatia (around $40 \%$ according to Поповић 2010: 75), USA, Canada or Western Europe. A small number even returned to Ukraine. As per the census carried out in 1991, the number of Ukrainians living in pre-war Bosnia and Herzegovina was 3929 (Council of Ministers, Bosnia and Herzegovina 2003: 34) but after numerous migrations caused by war and poor economic standards in the country the number of Ukrainians decreased to 1500-2000. This statistical information was given to us by Ukrainians of Prnjavor during interviews since the final results of the census conducted in 2013 have still not been released, due to a dispute between the statistical agencies of the Federation of Bosnia and Herzegovina and Republika Srpska (Jukić 2015).

The Ukrainian Greek-Catholic church, to which 98\% of the community belong, with the exception of 12 Orthodox families in the village Hrvaćani, has played a critical role in preserving their national, confessional and cultural identity (Savez nacionalnih manjina Republike Srpske 2015). The church remained not only a place where confessional rituals are conducted, but also a meeting point for practicing music, dance and the use of their mother tongue (Strehaljuk 1987). National cultural associations under the roof of the Coordinating Union of Ukrainian Associations and Organizations, such as: Cultural and Educational Association of Ukrainians „Červona kalena“" (formed in 2003, village Lišnja), Ukrainian Cultural and Educational Association „Taras Ševčenko“ (Prnjavor, formed before the second world war), Association of Ukrainians "Kozak" (Laktaši), Cultural and Educational Association of Ukrainians "Taras Ševčenko" (Banja Luka), the Canadian and Ukrainian Humanitarian Association "Veselka" (Trnopolje), the Association of Ukrainians "Ukrajinska Matica" (Banja Luka) and the Ukrainian association of creative intelligence „Svijet kul- 
ture" (formed in Prnjavor 2007) also have a significant role in preserving and developing the Ukrainian cultural heritage, mother tongue, customs and traditions by organizing choirs, folklore and drama clubs.

Decades long isolation from their homeland and the Serbian surroundings resulted in the development of a bicultural identity (term used as in: Berry, Trimble \& Olmedo 1986; Berry 1997) among the Ukrainians allowing them to feel comfortable and be proficient in both Ukrainian culture and local culture. However, data gathered during the fieldwork show that the level of biculturalism varies among individuals depending on their age and the ethnic composition of the family. Older members of the community and/or the ones with both parents more fluent in Ukrainian and more familiar with Ukrainian traditions, while the ones from mixed families still identify themselves as Ukrainians, referring to Ukrainian as their "mother tongue", but tend to use Serbian in everyday communication more often, which is becoming even more frequent among young people due to insufficient Ukrainian language competence.

The Ukrainians of Prnjavor are well integrated into the Serbian majority and the members of other minorities, participating both in exclusively Ukrainian cultural events such as the "Ukrainian ball" and in multicultural ones, such as Festival of National Minorities in Prnjavor"Little Europe" (Serbian: Mala Evropa) and other festivals, radio and TV-shows devoted to minorities. Due to the long presence of Ukrainians in this area, the cultural exchange has a bidirectional character: most local restaurants offer some of the popular traditional Ukrainian dishes (named in Serbian and local Ukrainian vernacular: piroge, boršč comparing to standard Ukrainian: вареники, боршч). In their interviews most of the Serbs were able to name some Ukrainian words or songs.

\section{Ukrainian Community in Republika Srpska - Its Language and National Identity}

The first wave of migrants from Western Ukraine who settled in Vojvodina during $18^{\text {th }}$ century, call themselves Ruthenians and use Ruthenian language (Bačka-Srem speech) in written and spoken form. In contrast, the Bosnian Ukrainians have identified themselves as Ukrainians and pub- 
lished their materials in Ukrainian from the moment of settlement. This was due to the fact that Ukrainian national identity was already formed at the moment of their migration (Поповић 2010: 75, Gustavsson 1998: 83), and also because their vernacular was (and remained) closer to Ukrainian standard than that of the Ruthenians from Vojvodina.

The language spoken by Bosnian Ukrainians is based on the Galician dialect of Ukrainian from the first half of the twentieth century, containing a lot of Polish words. Due to the constant contact with the Serbian speaking majority, it has incorporated a great number of loanwords from Serbian, mostly words for contemporary notions. That triggered the activation of those specific dialect characteristics which exist in Serbian and simplification of the paradigm of numerals (Українська мова: Енциклопедія: 73). At the same time Bosnian Ukrainian was not exposed to the influence of Russian during the $20^{\text {th }}$ century, which was the case with contemporary Ukrainian standard. Bosnian Ukrainian preserves some of the characteristics of the Southwestern group of dialects (mostly Upper Dniestrian and South Volynian speeches) such as: lower articulation of the vowel y (Ukrainian: и) when stressed (pronounced калена instead of калина), ending -ом in Instrumental case of feminine nouns (жінком, сестром), unification of case endings in genitive plural (е.g. селів instead of сіл), a large number of dialect words and many others (Українська мова: Енциклопедія 2004). For more detailed dialectological information see papers devoted to overall characteristic of the language spoken by Ukrainians in Bosnia and former Yugoslavia (Токар 1973;1972b) and to some of its specific aspects such as phonetics (Токар 1972a;1981b), morphology (such as declension of nouns of the I group Токар 1981a; past tense Токар 1982), lexical development (Токар 1991), structural and semantic organization of anthroponymy system (1997).

Bosnian Ukrainian vernacular is what Kloss $(1967$; 1987) called Aussenmudart, a dialect with a standard language used as a national language in another state, in this particular case - Ukraine. It is important to emphasize here that modern Ukrainian language, although it contains elements of all Ukrainian speeches, was based on writings of T.G. Ševčenko and Pantelejmon Kuliš, meaning on Eastern Ukrainian speeches (Шонц 2006: 235) - a different dialect group from the one spoken by the Ukrai- 
nian Diaspora. In consequence, Bosnian Ukrainians have to take into account their native dialect, standard Ukrainian, the neighboring dialect of the dominant Serbian language and its standard, which makes them tetraglossic (Gustavsson 1998: 80; Priestly 1997: 27-28) in the context of Republika Srpska and, even polyglossic in the context of Bosnia and Herzegovina's triple language situation caused by the restandardization process of the joint language standard into three separate national languages. A more detailed overview of the ethnic triglossia was given by Aleksandar Stojkanović (2015) in his $\mathrm{PhD}$ thesis in which he explains the reasons for the use of language as the means of ethnic (self) identification through strengthening of the symbolic role of the language over its communicative role in Bosnia and Herzegovina by analyzing the language policies and educational language policies of three of the constituent peoples. He underlines that the center of the language policy in Bosnia and Herzegovina is the community of identification rather than the community of communication. (Stojkanović 2015: 3) He sees the language as a primary ethnic symbol, which is used by the speakers to confirm and identify themselves as members of a particular ethnic, religious and political community (Stojkanović 2015: 3). A similar situation exists among the Ukrainians of Prnjavor, who use the term "mother tongue" (Serbian: maternji jezik, Ukrainian: рідна мова) for the Ukrainian language as a means of selfidentification, while at the same time they use Serbian language as the means of everyday communication.

It is important to point out that the absence of the Russian-Ukrainian bilingualism typical for Ukrainians in general differentiates Bosnian Ukrainians from the ones living in Ukraine and from contemporary Ukrainian labor migrants around the world - the absence of Russian-Ukrainian bilingualism typical for Ukrainians in general.

\section{Ukrainian Language in the Elementary Schools of Republika Srpska}

Bosnia and Herzegovina has continued SFRY's policy of tolerance and broad criteria toward national minorities (Stojkanović 2015: 165), which are defined by law as: 
"a part of the population-citizens of $\mathrm{BiH}$ that does not belong to any of the three constituent peoples and it shall include people of the same or similar ethnic origin, same or similar tradition, customs, religion, language, culture, and spirituality and close or related history and other characteristics" (Zakon o zaštiti prava pripadnika nacionalnih manjina 2003: Article 3).

The aforementioned law recognizes Ukrainians as one of the $17 \mathrm{mi}-$ norities and obligates the state to provide them

"Education in the minority language in the cities, municipalities, and inhabited areas in which the members of national minorities represent an absolute or relative minority"

And upon request "instructions on their language, literature, history, and culture in the language of the minority they belong to as additional classes" regardless of the number of the members of the national minority.

As far as organizational and financial issues are concerned,

"the Entity, cantonal, city and municipal authorities shall be bound to secure funds, means for the education of teachers to teach in the language of the national minority, to ensure the space and other requirements for the additional classes as well as printing of textbooks in the languages of national minorities." (Zakon o zaštiti prava pripadnika nacionalnih manjina 2003: Article 14).

Analyzing the educational language policies, in Bosnia and Herzegovina, Aleksandar Stojkanović (2015: 168) claims that, in spite of a good legislative basis for education in languages of national minorities, the application of these rights is, de facto, limited and without clear criteria for implementation. Explaining further that the institutions of $\mathrm{BiH}$ have not put in the effort to secure systematic and organized learning of minority languages, he identifies the following main problems: lack of qualified teachers able to give lectures in minority languages, lack of textbooks for learning minority languages and absence of contents about minorities in the current school curricula.

Within corresponding legislative framework, members of national minorities in Bosnia and Herzegovina have the following opportunities for learning their mother tongue: 
1. 72 lessons per school year of Italian and Ukrainian language and tradition each year, from $2^{\text {nd }}$ to $9^{\text {th }}$ grade, as a part of regular school system;

2. German language is taught at some elementary and high schools as a second language (which implies no lessons of history and tradition of the German minority),

3. Czech, Polish, Macedonian, Hungarian and Slovenian courses are organized by minority organizations (Stojkanović 2015: 172).

the Ukrainian language became part of the regular educational system of Bosnia and Herzegovina as a facultative course in 1965; in 1975 it was introduced as a regular teaching subject with its official curriculum (Strehaljuk 1984b: 190-192) and has remained in schools until the present with some discontinuation in the early nineties caused by the war.

Religious Education classes for Ukrainian children were introduced in the school year 1991/1992 firstly as a facultative course and from the next year as a regular one. According to the Third Report by Bosnia and Herzegovina on Legislative and Other Measures for the Implementation of Principles Seth Forth in the Framework Convention for the Protection of National Minorities, Ukrainian language is taught in "Desanka Maksimović" School in Trn (Laktaši Municipality) from the second half of school year 2010/2011 as well as in elementary schools in Prnjavor and satellite schools in the Municipality of Prnjavor - Hrvacani, Potocani, Lišnja and the village of Trnopolje near Kozarac, which belongs to the Municipality of Prijedor (Council of Ministers, Bosnia and Herzegovina 2012: 22).

Ukrainian language classes were previously held in Banja Luka (Strehaljuk 1987) and there was an initiative on reintroducing them, but this is still in process (Council of Ministers, Bosnia and Herzegovina 2012: 22). There are no conditions either for providing members of Ukrainian minority with the possibility to obtain education in Ukrainian or for introducing other Ukrainian-specific school subjects. Ukrainian as a heritage language is at present taught only in elementary schools, while there aren't any Ukrainian classes in pre-schools, high schools or universities.

Outside of the school system, Ukrainian language and culture are being taught at summer schools organized in local monasteries with fi- 
nancial support from the Ukrainian Diaspora in Canada. Summer schools developed from the tradition of Ukrainian-Ruthenian Youth seminars held from 1965 to 1983 in Bosnia and Herzegovina, Croatia and Vojvodina (Serbia). Not only the language, but also geography, history, ethnology, music, choreography and handicrafts were taught at those seminars, four of which were held in Bosnia and Herzegovina: in 1966 - Prnjavor, 1971 Mrakovica, 1976 - Banjaluka, 1979 - Čelinac (Strehaljuk 1984b).

\section{Present Research: Goals and Methodology}

Field research was conducted in November 2014 in Prnjavor as a part of the project Language Folklore, Migrations in the Balkans (Institute for Balkan Studies SASA, Belgrade) in cooperation with the Faculty of Philology, University of Banja Luka, project Research and Protection of the intangible cultural heritage of Republika Srpska with the aim of getting insight into community life and gathering data on Ukrainian as a heritage language within the educational system of Republika Srpska.

The research methodology was qualitative in nature - data were collected by using the following sociolinguistic research techniques: direct observation and participation observation (visits to Ukrainian lessons in elementary schools in Prnjavor ("Nikola Tesla" and "Branko Ćopić") and Lišnja ("Meša Selimović"), unrecorded informal interviews with school principals including taking field notes, semi-structured narrative interviews with Ukrainian language teacher and other members of the community.

Prior to the interviews and recording the lessons, a short pre-interview was conducted with each participant or group of participants in order to get them acquainted with the aims of the research and get their consent for making audio recordings and/or photos.

Quantitative data were obtained from school documentation, such as journals, school yearbooks and chronicles containing reports on work of the schools, the annual work plan for Ukrainian language lessons for the school year 2014/2015.

The present paper aims to give an overall picture of the current state of Ukrainian as a heritage language in schools of Republika Srpska (Prn- 
javor), highlight the main issues and challenges Ukrainians face in the process of acquisition of the Ukrainian language at school and introduce a new set of questions for future research work.

\section{Results}

Analysis of the available school chronicles of the visited schools allowed us to obtain the following data on "Ukrainian as a nationality language" lessons:

\begin{tabular}{|c|c|c|c|}
\hline & $\begin{array}{l}\text { "Nikola Tesla" } \\
\text { Elementary School, } \\
\text { (Prnjavor) }\end{array}$ & $\begin{array}{l}\text { "Branko Ćopić" } \\
\text { Elementary School, } \\
\text { (Prnjavor) }\end{array}$ & $\begin{array}{l}\text { "Meša Selimović " } \\
\text { Elementary School, } \\
\text { (Naseobina Lišnja) }\end{array}$ \\
\hline $\begin{array}{l}\text { Introduction } \\
\text { of Ukrainian } \\
\text { classes }\end{array}$ & $\begin{array}{l}\text { No exact data; first } \\
\text { mention in the chronicle } \\
\text { is } 1982 / 1983\end{array}$ & $\begin{array}{l}\text { School was founded } \\
\text { in } 1985 \text { and Ukrainian } \\
\text { classes were held from } \\
\text { the beginning. }\end{array}$ & $\begin{array}{l}\text { No exact data, over } \\
30 \text { years; }\end{array}$ \\
\hline $\begin{array}{l}\text { Important data } \\
\text { from school } \\
\text { chronicles and } \\
\text { repots }\end{array}$ & $\begin{array}{l}\text { Year 1982/1983: Czech } \\
\text { and Ukrainian minority } \\
\text { show low interest for } \\
\text { language courses; } \\
\text { Year 1986/1987: } 88 \\
\text { students attended } \\
\text { Ukrainian language } \\
\text { classes (optional); } \\
\text { Year 1991/1992: } \\
\text { Ukrainian Religious } \\
\text { Education classes } \\
\text { introduced; } \\
\text { Year 2006/2007: The } \\
\text { teacher changed and the } \\
\text { number of the pupils } \\
\text { significantly decreased; }\end{array}$ & $\begin{array}{l}\text { Year 1990/1991 - } \\
\text { 2006/2007: Ukrainian } \\
\text { language classes are } \\
\text { held by Snježana } \\
\text { Petršin; 25-29 students } \\
\text { attending, folklore } \\
\text { section; } \\
\text { Year 2006/2007: } \\
18 \text { students started } \\
\text { attending classes; } 13 \\
\text { left after the change of } \\
\text { the teacher; } 6 \text { students } \\
\text { attending classes (5 } \\
\text { old, } 1 \text { new); } \\
\text { Ukrainian Religious } \\
\text { Education classes; }\end{array}$ & $\begin{array}{l}\text { Ukrainian language } \\
\text { classes are held for } \\
\text { over } 30 \text { years (no } \\
\text { exact data); } \\
\text { Ukrainian } \\
\text { Religious education } \\
\text { classes are held; } \\
\text { No folklore section; }\end{array}$ \\
\hline $\begin{array}{l}\text { School year } \\
2014 / 2015\end{array}$ & $\begin{array}{l}24 \text { Ukrainian students, } \\
4 \text { of them attending } \\
\text { Ukrainian classes } \\
(17 \%) ;\end{array}$ & 4 students out of 22 & $\begin{array}{l}3 \text { students are } \\
\text { attending Ukrainian } \\
\text { classes, no data on } \\
\text { overall number of } \\
\text { Ukrainian students }\end{array}$ \\
\hline
\end{tabular}


During our visits to schools and interviews with the teacher, pupils and the principals, the following types of problems and issues were identified: organizational, financial, motivational, interpersonal communication and competence issues, which all together lead to a decrease in the number of students learning Ukrainian at school.

Almost the same organizational issues in teaching Ukrainian at elementary schools were seen as described in the corresponding paper written three decades ago (Strehaljuk 1984a) such as: problems with the schedule and group management or low support for the teachers, lack of opportunities for the teachers to obtain education in Ukrainian and attend training and seminars are still present. "Ukrainian as a nationality language" is taught in additional classes to Ukrainian minority pupils apart from regular classes, meaning before all other lessons (7.15) or between two school shifts, during the time provided for extracurricular activities, classes with homeroom teachers, visits, compensation classes, etc. Due to a low number of pupils Ukrainian classes are held at the same time for all of the pupils, regardless of their age and previous knowledge. Therefore, the teacher has to work individually with 3-5 students using 3-5 different programs at the same time in one classroom. These circumstances define the choice of teaching methods: students usually read texts, copy them, and translate them in written or oral form, without the possibility for developing communicative competences. The situation is somehow better with cultural competences, because students write and learn about important elements of Ukrainian national culture together and are especially interested in learning Ukrainian songs. Ukrainian classes are also used as rehearsals of songs and poems that pupils perform at school plays and minority radio shows.

During the interviews not only Ukrainian language teacher, but also other members of Ukrainian community underlined the importance of financial support for preserving their language and national identity. As far as Ukrainian lessons at schools are concerned, schools are faced with a lack of appropriate teaching and learning support materials. At the time of the interviews, only a few students had a student book, which resulted in dictation and copying as the only possible methods of working with texts and led to many classes held in the form of writing, reading and memorizing lists of words obtained from the teacher's graduate work, mostly ones, related to everyday life and agriculture. 
Considering the fact that there are no Ukrainian studies at any of the universities of Bosnia and Herzegovina (or any other form of seminars or workshops designed for Ukrainian language teachers), teachers have always had to work on obtaining professional qualifications individually (Strehaljuk 1984b). Until school year 2006/2007 classes were held by other subject teachers of Ukrainian nationality born and raised in Republika Srpska, which meant that the pupils had only the opportunity to learn the language of their ancestors who colonized Bosnia at the end of the $19^{\text {th }}$ century. The current Ukrainian language teacher is a native speaker of the Bosnian Ukrainian vernacular, who graduated from the Faculty of Philology in Ukraine and was exposed to Ukrainian Standard during some period of her life. Nevertheless, the teacher experiences the same type of interference as pupils (naturally, to a lesser extent) and gives preference to usages present in the local dialect, which gives the students limited access to the Standard Language and limits their communicative competence (e.g. students showed no reaction to the most common Ukrainian forms of address-

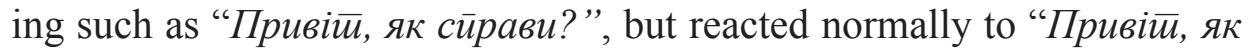
ся маєш?" typical for Western Ukraine etc.).

Analysis of the recordings from the classes showed the following issues among the pupils: they deal with the same types of interference in learning Ukrainian language as Serbian students learning Ukrainian as a foreign language, such as usage of specific letters Я, $\mathrm{C}$, Ю, İ; misuse of I and $И$ (for a detailed review of typical orthographic errors characteristic for Serbian students learning Ukrainian see: Василієвич 2013), misuse of stress, Serbian accent etc, and the ones typical for the language of Ukrainian Diaspora, such as mixing $\mathrm{E}$ and $И$ both in written and oral form. Examples of code-switching in single one sentence during the lessons are fairly frequent and used mostly by the teacher, e.g.:

Що ми сиівали zа Uskrs, za Воžić? (e.t.: What did we sing (Ukr.) for Easter, for Christmas (Serb?)

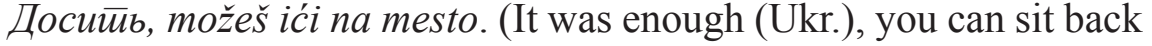
down (Serb). with seldom examples of, rather intuitive than deliberate, translanguaging:

Ja sam vas opomenula (I warned you (Serb), йоиересила (warned $\mathrm{Ukr}$ ), da će gosti doći (that the guests are coming - Serb). 
As far as cultural competences are concerned, pupils show a good knowledge of traditions characteristic for Ukrainians in Bosnia based on their personal experience (rituals and customs are, unlike the language, being practiced on a regular basis) and superficial knowledge of key concepts of Ukrainian culture, which are taught to them in Serbian and are not a part of their everyday life.

In general, pupils rarely have the opportunity to use Ukrainian language outside the classroom and the folklore sections, and there is a significant difference in knowledge and interest in learning the language among kids, depending on the family.

Interpersonal communication and relations inside the Ukrainian community have a very significant influence on learning Ukrainian language at schools - with the change of the teacher in the school year 2006/7 the number of the students attending Ukrainian classes decreased from 35 to 6 (KRUTO 2007: AD/2) and the current state (absence of any extracurricular activity in Ukrainian, such as folklore or drama section, which existed in the past; the larger number of children attending Ukrainian Religious Education than Ukrainian as a nationality language classes) shows that the dynamic of social relations among the community members represents a strong demotivational factor for language learners and, especially, their parents.

\section{Conclusions and Future Research}

The field research exposed a large variety of challenges Ukrainians face in the process of language learning at school. Some of them are characteristic for the members of other minorities in Bosnia and Herzegovina - organizational and financial problems, lack of training for teachers, while others are characteristic of the Ukrainian community, such as disputes among the community members, which contribute to decreases in the number of the students learning the language and also (by causing animosity between parents and the teacher and involving the school authorities) suspension of extracurricular activities.

Considering the fact, that Ukrainians in general have good relations with the local majority and are not struggling with any deliberate discrim- 
ination, the main work on preserving the language should be aimed at increasing the financial and institutional support from the state and raising the descendants' awareness of the importance of learning their ancestral language both at school and in families, by regular and systematic intergenerational transmission.

For further planning of the systematic and well-organized learning of Ukrainian language within the primary educational system of Republika Srpska, it is necessary to resolve the dilemma which variety of Ukrainian language should be taught at schools and for what purposes:

1. Standard Ukrainian language, which would be almost a foreign language for pupils, but would give them the possibility to communicate with Ukrainians in Ukraine and, possibly, obtain academic language proficiency (CALP) necessary for studies or work in Ukraine;

2. or Bosnian Ukrainian, which is an archaic variety of a dialect, but is familiar to students and to some extent used in the everyday life of the community, the study of which would help pupils develop basic interpersonal communicative skills (BISC).

In terms of future research work on the Ukrainians of Bosnia and their language, we see the following possible directions of work:

1. sociolinguistic research work on language attitudes, use and role of Ukrainian language in different spheres, analysis of educational language policies, determination of the type of Ukrainian-Serbian bilingualism and code-switching;

2. eco-linguistic research work on language maintenance and possible work on its revitalization;

3. applied linguistic research work on exploring the interference issues, development of different language competences in Ukrainian, finding optimal teaching methods and tools for teaching Ukrainian as a heritage language and overcoming current teaching and learning issues;

4. Additional dialectological work on characteristics of Bosnian Ukrainian variety which would show its present state and the changes that happened from the last study conducted in early seventies. 


\section{References:}

Белей, Л. (2008).Українці та українська мова на Балканах (Сербія, Хорватія, Боснія і Герцеговина), Дивослово, 8, 42-48.

Василієвич, Д. (2013). Орфографічні помилки сербських студентів на початковому етапі вивчення української мови як іноземної. У: Теорія і ирракиичка виклаgання української мови як іноземної: Збірник наукових ӣращь, 8, 150-158.

Головчук, П. (2007). Про освіту в Дев’ятині (Перша половина ХХ століття). Українське слово: Вияання йоварисивва «Просвійа», 3, 38-39.

Журжа I. В. (2014). Русини чи українці: українська діаспора на південнослов'янських землях. Поліӣолойічні заииски, 2, 149-154.

Коваль А.П. (1967). Українці в Югославії. Мовознавстиво, 2, 53-56.

Козлітін, В. (1996). Українські громадські організації в Югославії (20 - 30-ті рр. ХХ ст.). Українська gіасйора, 9, 48-57.

Латяк, Ю. (2000). Інформування українською мовою на просторах колишньої Югославії (1922-1992). Глас союзу: Союз русинів $i$ украӥнців Сербії і Чорноїорії, 3, 50-54.

Ліський, Б. (1997). Огляд культурно-освітнього життя українців у Боснії 1890-1990 рр. Украӥнська gіасйора, 10, 32-50.

Малиновська О. (1995). Українська діаспора в південнослов'янських землях: короткий історичний нарис. Украӥнська giacūopa, 8, 12-28.

Марунчак М. (1969). Українці в Румунії, Чехословаччині, Польщъі, Юīocлавіï. Winnipeg: New Pathway Publishers Ltd.

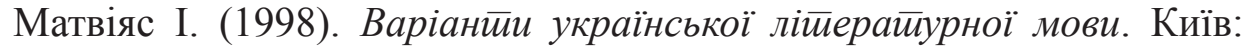
НАН України. Інститут укр. мови.

Микитенко, О.О. (2012). Фольклор як чинник ідентичності українців на теренах колишньої Югославії У: Борисенко В.К та ін. (ред. кол.). Традиційна культура діаспори. (с. 303-319). Одеса: Одеський національний університет імені I.I. Мечникова.

Небесниј, Б. (2007). Украјинци у Србији. У: Положај нащионалних мањина у Србији: зборник раяова са научной скуйа оgржаної 2426. новембра 2005. (стр. 541-554). Београд: САНУ.

Поповић, Љ. (2010). Русини и Украјинци у Србији. Зборник Майице Срйске за славистиику, 78, 69-99. 
Румянцев, О. (2008). Галичина - Боснія - Воєвоgина: Украӥнські иереселенці з Галичини на ииерийорії юі̄ославських нароgів у 1890-1990 рр. Київ: ФАДА, ЛТД.

Румянцев, О. (2010). Пийання національної іgенииччностиі русинів $i$ українців Юіославї (1918 - 1991). München - Berlin: Verlag Otto Sagner.

Саган, Г. (2014). Відродження громадських і культурних інституцій українців у 50-70-тіроки ХХстоліття в БосніїіГерцеговині, Україна у свійовій істиорії, 3 (52), 175-183.

Стојкановић, А. (2015). Сочиолинівисииичка анализа језичке иолийике

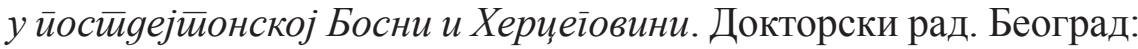
Филолошки факултет.

Стрехалюк, В. (1985) Про мову, якою спілкуються югославські українці. Наша яумка, 49, 38-39.

Токар, Т.Я. (1972а). Про фонетичні субститути в сербохорватських словах, вживаних українськими поселенцями Боснії. У:Баранник Д.Х. (отв. ред.). Некойорые войросы современной истиорической науки и филолоїии. (стр. 132-137). Днепропетровск: М-во высш. и сред. спец. образования СССР. Днепропетр. гос. ун-т им. 300-летия воссоединения Украины с Россией.

Токар, Т.Я. (1972b) Українські поселення в Югославії і вивчення їх говорів. У: Ващенко В.С. (відп. ред.) Пийання украӥнської

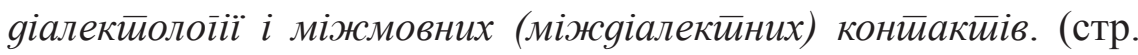
86-89). Дніпропетровськ.

Токар Т. Я. (1973). Сисиемма словозміни українських іовірок Боснї (Юїославія). Unpublished doctoral dissertation. Дніпропетр. держ. ун-т ім. 300-річчя возз'єднання України з Росією.

Токар, Т. Я. (1981a). Дісслова минулого часу в українських говірках Босніі. У Туркин, В.Н. (отв. ред.) Войросы лексики и іраммайики славянских языков: сборник научных йруgов (стр. 68-72). Днепропетровск : ДГУ.

Tokar, T. (1981b). Prilog proučavanju fonetskih osobenosti ukrajinskih govora u Bosni, Radovi ANUBiH, knj. LXX, Odjeljenje društvenih nauka, knj. 21, 211-216.

Токар Т.Я. (1982). Відмінювання іменників I відміни в українських 
говірках Боснії. У Матвіяс. І.Г. (відп. ред.) (1982). Сӣрукӣура украӥнських іоворів: 3б. сй. (стр. 113-118). Київ: Наукова думка. Токар, Т.Я.(1991). До питання розвитку лексики українських острівних говірок Боснії. У: Гриценко П.Ю. (відп. ред.). Досліgження 3 украӥнської яіалекииолоїї : Збірник наукових ирацьь (стр. 140151). Київ: АН України, Ін-т мовознавства ім. О.О. Потебні, Наукова думка.

Токар, Т. Я. (1997). До питання структурно-семантичної організації антропонімікону українських говірок Боснії In Горпинич В.О. (відп. ред.) “Питиання сучасної ономастиики”, всеукр. ономас-

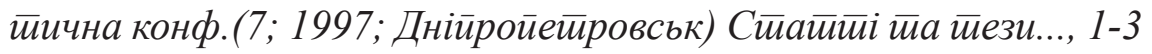
жовйня, 1997.(стр. 140-151). Дніпропетровськ: Дніпропетровський держ. ун-т.

Терлюк, І. (1996). «Просвіта» - берегиня національної ідентичності. Українське слово, 1, 35-37.

“Українська мова в Сербії, Боснії і Герцеговині, Хорватії.” Українська мова: Енциклойеgія. Редкол. Русанівський В.М., Тараненко О.О., Зяблюк М.П. та ін. - 2-ге вид., випр. і доп. - К. : Вид-во "Українська енциклопедія" ім. М.П.Бажана, 2004. 731.

Шонц, О. П. (2006). Діалектне підгрунтя вимовних норм української літературної мови. Слов'янський збірник, ХII, 234-244.

Berry J.W. (1997). Immigration, acculturation, and adaptation. Applied Psychology: An International Review, 46, 5-34.

Berry, J.W., Trimble, J.E. \& Olmedo, E.L. (1986) Assessment of acculturation. In W Lonner and J Berry (Eds). Field methods in cross-cultural research (pp. 291-324). Newbury Park, CA: Sage.

Council of Ministers, Bosnia and Herzegovina (2003). Report of Bosnia and Herzegovina on Legal and other Measures on Implementation of the Principles Determined in The Framework Convention for the Protection of National Minorities. Retrieved on May 24, 2005 from https:/www.coe.int/t/dghl/monitoring/minorities/3_FCNMdocs/ PDF_1st_SR_BiH_en.pdf.

Council of Ministers, Bosnia and Herzegovina (2012). Third Report of Bosnia and Herzegovina on Legal and other Measures on 
Implementation of the Principles Determined in The Framework Convention for the Protection of National Minorities. Retrieved on May 25, 2005 from https://www.coe.int/t/dghl/monitoring/ minorities/3_FCNMdocs/PDF_3rd_SR_BiH_en.pdf.

Gustavsson, S. (1998). Sociolinguistic Typology of Slavic Minority Languages. Slovo, 46, 75-89.

Jukić, E.M. (2015). Disputes delay Publication of Bosnia Census. Balkan Insight. Retrieved January 25, 2016, from http://www.balkaninsight. com/en/article/political-disputes-delay-publication-of-bosnia-scensus-results.

Kloss, H. (1967). Abstand Languages and Ausbau Languages, Anthropological Linguistics 99, 7, pp. 29-41.

Kloss, H. (1987). Abstandsprache und Ausbausprache. In Ammon, U.,Dittmar, N., Mattheier, K.J. Sociolinguistics. An International Handbook of the science of Language and Society. (pp. 302-308). Berlin. New York: Walter de Gruyter.

Krojcar, I. (1927). Ukrajinska emigracija u Jugoslaviji. Ruski kalendar za južno-slavjanskih Rusinok, 113-115.

KRUTO. (2007). Zapisnik sa druge (02/2007) sjednice Predsjedništva Koordinacionog saveza ukrajinskih udruženja $i$ organizacija održane 20. 05. 2007. Retrieved April 20, 2015 from http://kruto-bl. com/zapisnik\%20sa\%20druge\%20sjednice.html.

Savez nacionalnih manjina Republike Srpske. Ukrajinci. Retrieved December 23, 2015, from http://www.snm.rs.ba/208/snm/ Ukrajinci/u/Bosni/i/Hercegovini.

Priestly, T. (1997). Dialect literature: its importance in the maintenance of a minority language (Slovene in Austria). In Synak, B., Wicherkiewicz, T. (ed.) Language Minorities and Minority Language in the Changing Europe. (pp. 115-130). Gdansk: Wydawnictwo Uniwersytetu Gdanskiego.

Sabadoš, J. (1973). Uticaj odvojenog tretiranja rusinske od ukrajinske narodnosti u Jugoslaviji na njen kulturni i politički život. Magistarski rad. Beograd: Fakultet političkih nauka.

Sabadoš, J. (1971). Problemi na liniji opredeljivanja Rusin-Ukrajinac kod ove narodnosti u SFRJ. U: Laćak, Đ., Radovanović, M. (ur.). 
Tradicionalna kultura jugoslovenskih Rusina (prilozi). (str. 239287). Novi Sad: Ruske slovo.

Sančanin, N. (2005). Dvije otadžbine u srcu. Laktaši: Gratomark.

Strehaljuk, V. (1984a). Mjesto nastave jezika narodnosti u našoj školi. Nastava, 1, (2), 116-123.

Strehaljuk, V. (1984b). Jezici narodnosti u našoj školi. U: Šipka, M. (ur.). Jezik i nacionalni odnosi. Sveske Instituta za proučavanje nacionalnih odnosa II. 5-6. (str. 185-194). Sarajevo: Institut za proučavanje nacionalnih odnosa.

Strehaljuk, V. (1987). Ukrajinci u osnovnom obrazovanju BiH. Nastava, 1, Br. 1 (8), 95-100.

Strehaljuk V. (1980). Ukrajinci u Bosni, Godišnjak društva istoričara Vojvodine, 1978, 77-93.

Zakon o zaštiti prava pripadnika nacionalnih manjina. (2003). Službeni glasnik Bosne i Hercegovine,VII-12. Sarajevo: JPNO Službeni list $\mathrm{BiH}$.

\begin{abstract}
Due to a long-term lack of contact with their homeland and large number of mixed marriages, Bosnian Ukrainians speak a very different language from the one spoken in contemporary Ukraine. For most of the population Ukrainian is no longer L1 and their national identity is mostly conserved in church and customs (celebrations, traditions, folklore) while the language itself has a secondary role.

Field research devoted to Ukrainian as a heritage language in elementary schools of Republika Srpska was conducted in Prnjavor and Naseobina Lišnja in November 2014. The following main issues and challenges Ukrainians face in the process of language acquisition at school were identified: insufficient funds, low interest among parents, scarce and inappropriate teaching and learning support materials, organizational issues at schools and lack of Ukrainian-based extracurricular activities.
\end{abstract}

Keywords: Ukrainian as a heritage language, Ukrainian Diaspora, Bosnian Ukrainians, Minorities of Republika Srpska. 


\section{Biographical statement}

DRAGANA VASILIJEVIĆ is a linguist, MA. During her Master's program in Slavic Studies at the University of Belgrade she conducted research on political discourse, which resulted in a master's thesis "The Discourse of Political Advertising in Serbian, Russian and Ukrainian” and a series of published papers. Since 2013, she is enrolled in $\mathrm{PhD}$ studies at the Faculty of Philology (University of Belgrade) and since 2014, a scholarship holder, associated to the project "Language, Folklore and Migrations in the Balkans" at the Institute for Balkan Studies (Serbian Academy of Sciences and Arts, Belgrade). She is currently working on her PhD thesis devoted to Bosnian Ukrainians and their language. Main research interests: minority languages, CDA, political discourse.

E-mail: dr.vas381@gmail.com 